\title{
POTENSI EKONOMI PERKEBUNAN JERUK SIAM NAGARI PANDAM GADANG KECAMATAN GUNUANG OMEH KABUPATEN LIMA PULUH KOTA Ayu Ashari ${ }^{1}$ Program Studi Geografi \\ Fakultas Ilmu Sosial Universitas Negeri Padang Email ashariayu16@gmail.com
}

\begin{abstract}
ABSTRAK
Tujuan penelitian ini yaitu mengetahui potensi ekonomi perkebunan jeruk siam di nilai dari segi produksi, harga jual, pendapatan dan mengetahui faktor-faktor yang mempengaruhi potensi ekonomi perkebunan jeruk siam Pandam Gadang Kecamatan Gunuang Omeh Kabupaten Lima Puluh Kota. Jenis penelitian ini yaitu kuantilatif (Mixed Methods). Metode penelitian kombinasi (mixed methods) adalah suatu metode penelitian yang mengkombinasikan metode kuantitatif dan metode kualitatif untuk digunakan secara bersama-sama dalam suatu kegiatan penelitian sehingga diperoleh data. Hasil penelitian menunjukkan bahwa potensi ekonomi perkebunan jeruk siam Pandam Gadang Kecamatan Gunuang Omeh dapat dilihat dari produksi jeruk, harga jual, serta pendapatan petani setiap kali panen jeruk. Dimana faktor-faktor yang mempenguruhi potensi ekonomi perkebunan jeruk antara lain, luas lahan.
\end{abstract}

Kata Kunci : Potensi Ekonomi, Perkebunan, Jeruk Siam Gunuang Omeh

\begin{abstract}
The purpose of this study is to know the Potential of Citrus Plantation Economic Siam in value in terms of production, selling price, income and know the factors that affect the Potential Economic Citrus Plantation Siam Pandam Gadang District Gunuang Omeh District Lima Puluh Kota. This type of research is quantitative (Mixed Methods). Mixed methods is a research method that combines quantitative and qualitative methods to be used jointly in a research activity to obtain data. The results showed that the economic potential of Siam Pandam Godang Plantation of Gunuang Omeh Subdistrict can be seen from the production of citrus, the selling price, and the income of the farmer whenever the citrus harvest. Where the factors that mempgeruruhi economic potential Citrus Plantation, among others, the area of land.
\end{abstract}

Keywords: Economic Potential, Farmer, Siamese Citrus Gunuang Omeh

${ }^{1}$ Mahasiswa Program Studi Geografi untuk wisuda Maret 2018 


\section{PENDAHULUAN}

Jeruk merupakan salah satu tanaman buah yang penting dan dibudidayakan secara luas di Indonesia. Hal ini terlihat dari total produksi jeruk di Indonesia menduduki peringkat kedua setelah pisang dengan angka 1,8 juta ton(BPS,2017)

Menghadapi biaya produksi yang tinggi, petani meminjam pada pengumpul hasil panen. Sering terjadi dana yang dipinjam petani masih belum mencukupi akibatnya petani menambah jumlah pinjamannya dari pengumpul hasil panen atau para petani menyediakan sarana produksi yang lebih kecil dari semestinya sehingga berakibat pada hasil panen yang tidak optimal .

Perkembangan atau pertambahan produksi dalam kegiatan ekonomi tidak lepas dari peranan faktor-faktor produksi atau input. Untuk menaikkan jumlah output yang diproduksi dalam perekonomian dengan faktor-faktor produksi, para ahli teori pertumbuhan neoklasik menggunakan konsep produksi (Dornbusch dan Fischer, 2001). fungsi produksi adalah hubungan teknis yang menghubungkan antara faktor produksi (input) dan hasil produksi (output). Disebut faktor produksi karena bersifat mutlak, supaya produksi dapat dijalankan untuk menghasilkan produk.

Keputusan harga jual merupakan keputusan yang sulit, karena adanya faktor-faktor yang terlibat dalam pembuatan keputusan tersebut, baik faktor intern maupun ekstern, sehingga perlu pertimbangan mendalam dan teliti untuk memperoleh harga jual yang benar sesuai keinginan dan tujuan perusahaan

Dalam usahatani, pemilikan dan penguasaan lahan sempit sudah pasti kurang efisien dibanding lahan yang lebih luas, kecuali bila usahatani itu dijalankan dengan teknologi yang tepat. Pada luasan yang lebih sempit, penerapan teknologi cenderung berlebihan (hal ini erat hubungannya dengan konversi luas lahan ke hektar) dan menjadikan usahatani tidak efisien. Namun pada usahatani yang memiliki lahan yang cukup luas, juga sering terjadi ketidakefisienan dalam penggunaan teknologi. Hal ini terjadi apabila usahatani tidak dijalankan dengan manajemen yang baik dan terarah (Daniel, 2004).

Risiko berpengaruh terhadap pengambilan atau perilaku petani (Soekartawi, 1986). Petani yang takut terhadap risiko produksi mengalokasikan input yang lebih sedikit dibandingkan dengan petani yang menyukai risiko. Semakin berani petani dalam menghadapi risiko maka input yang dialokasikan semakin besar. Perilaku petani yang menghindari risiko menyebabkan alokasi penggunaan input tidak efisien, sehingga pada akhirnya 
berpengaruh terhadap tingkat produktivitas usahatani.

Dibalik kualitas jeruk yang sangat bagus dan nilai jual yang tinggi, tidak bisa dipungkiri bahwa para petani jeruk siam terbebas dari persoalan ekonomi yang ada. Keberadaan para petani saat ini dalam meningkatkan jumlah panen dan nilai jual jeruk masih terkendala dengan beberapa persoalan seperti kondisi jalan yang belum bagus, luas lahan yang belum memadai, nilai jual yang tidak sebanding dengan jumlah hasil panen jeruk yang dihasilkan, serta kurangnya perhatian dari pemerintah setempat dalam memberikan sumber dana serta pelatihan dan inovasi kepada para petani dalam mengembangkan usaha tani jeruk.

Saat ini kelompok tani jeruk yang ada masih minim dengan sumber daya manusia yang berkualitas untuk mengembangkan jeruk siam Pandam Gadang menjadi jenis jeruk unggulan. Jika kelompok tani ini memiliki sumber daya yang berkualitas tidak menutup kemungkinan jenis jeruk siam Gunuang Omeh ini mampu menjadi importir utama jeruk ke seluruh dunia.

Tentu untuk mencapai itu semua perlu kerja keras dari para petani dan pihak terkait untuk meningkatkan potensi ekonomi jeruk siam yang ada di Pandam Gadang. Semua persoalan yang ada harus segera diselesaikan secara bersama agar potensi yang ada pada saat ini dapat dikembangkan menjadi jeruk yang memiliki nilai jual yang tinggi dan jumlah panen yang meningkat setiap tahunnya serta mampu bersaing di dunia pasar baik dari segi harga maupun kualitas rasa yang dihasilkan dari jenis jeruk siam Pandam Gadang.

Salah satu bentuk potensi yang bisa dikembangkan oleh petani jeruk maupun kelompok tani Pandam Godang adalah menjadikan lahan pertanian jeruk menjadi agrobisinis jeruk. Jika para petani mampu mengembangkan lahan pertanian jeruk menjadi agrobisnis jeruk tentu hal ini menjadi nilai ekonomis bagi para petani dan masyarakat sekitar untuk meningkatkan ekonominya.

Setiap wisatawan yang berkunjung dapat memetik dan menikmati buah jeruk siam Gunuang Omeh langsung dari kebunnya dengan ketentuan dan syarat biaya yang harus dipenuhi oleh wisatawan yang berkunjung ke lahan pertanian jeruk Gunuang Omeh. Selain hasil jeruk yang melimpah, lokasi perkebunan jeruk juga bisa dikelola sebagai agrowisata bagi masyarakat yang berkunjung ke perkebunan jeruk Gunung Omeh ini. 


\section{METODE PENELITIAN}

Jenis penelitian ini menggunakan metode penelitian kombinasi (Mixed Methods). Menurut Sugiyono (2011:404) bahwa, Metode penelitian kombinasi (mixed methods) adalah suatu metode penelitian yang mengkombinasikan atau menggabungkan antara metode kuantitatif dan metode kualitatif untuk digunakan secara bersamasama dalam suatu kegiatan penelitian sehingga diperoleh data yang lebih komprehensif, valid, reliabel dan objektif.

Lokasi penelitian dilakukan di . Nagari Pandam Gadang Kecamatan Gunuang Omeh Kabupaten Lima Puluh Kota. Lokasi penelitian bisa dilihat pada gambar 1 .

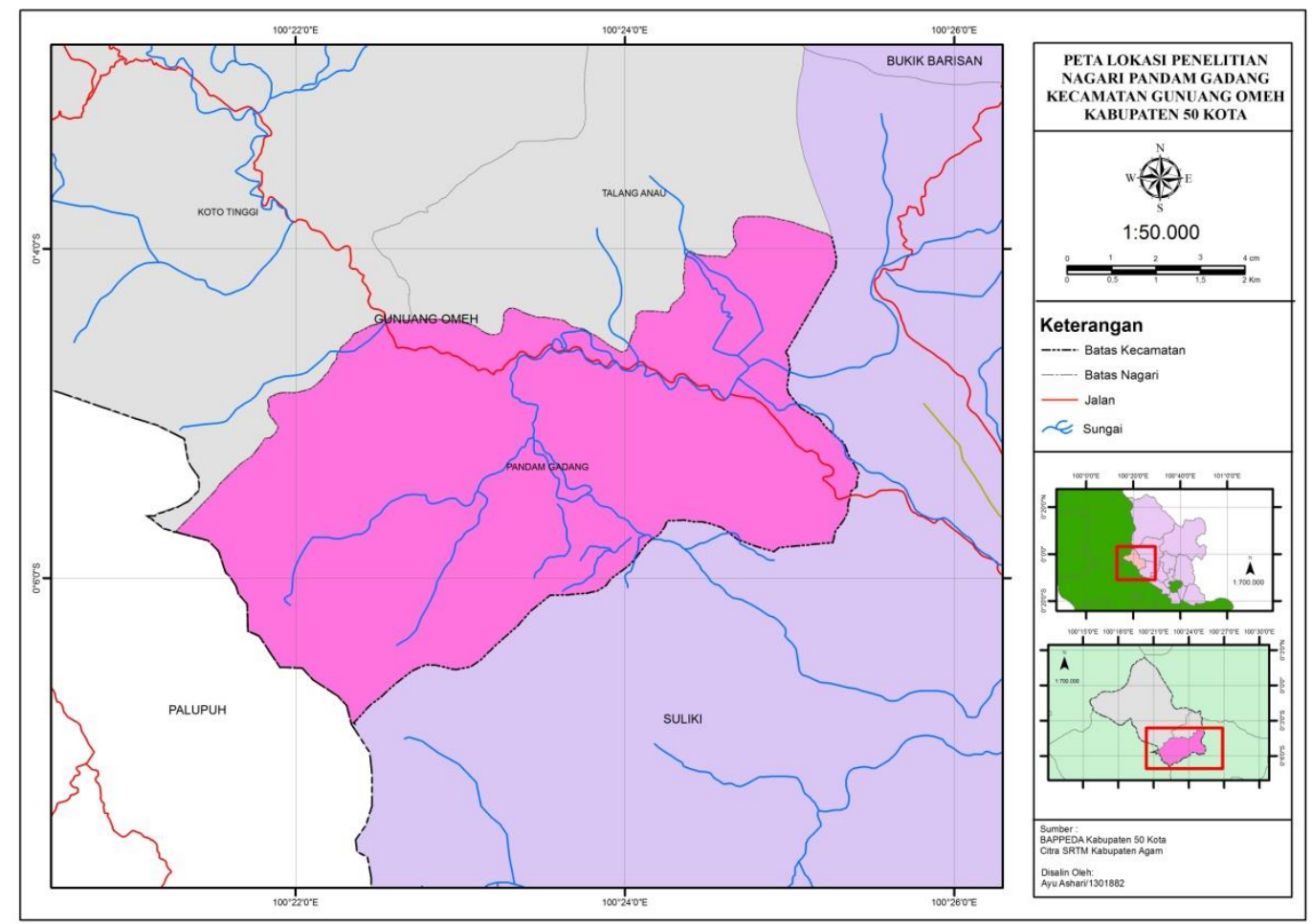

Gambar 1. peta lokasi penelitian

Populasi di wilayah ini adalah seluruh penduduk di Nagari Pandam Gadang kecamatan Gunuang Omeh terdapat di wilayah tersebut.

Metode pengambilan sampel pada penelitian ini dilakukan dengan cara purposive sampling (sampel bertujuan), Penduduk yang diwawancarai adalah petani jeruk.
Data yang di gunakan dalam penelitian ini adalah data primer dan sekunder. Data primer dalam penelitian ini adalah wawancara dengan masyarakat setempat.

Data sekunder penelitian ini diperoleh dari BPS Kecamatan Gunuang Omeh dan data statistik tanaman pangan, hortikultural dan perkebunan tahun 2015 . 
Teknik analisis data yang di gunakan dalam penelitian sesuai dengan rumusan masalah adalah metode analisa yang dipakai dalam penelitian kualitatif melalui beberapa tahap analisa data yaitu : 1 . pengumpulan data, 2. reduksi data, 3 . penyajian data, 4. kesimpulan dan Kuntitatif Dengan rumus sebagai berikut :

$$
P=\frac{f}{N} x 100 \%
$$

Keterangan :

$$
\begin{array}{ll}
\mathrm{P} & : \text { Presentase } \\
\mathrm{F} & : \text { Frequensi jawaban } \\
& \text { responden } \\
\mathrm{N} & : \text { Jumlah Responden }
\end{array}
$$

(Sudjana: 2007: 129)

\section{HASIL DAN PEMBAHASAN}

1.Potensi Ekonomi Perkebunan Jeruk Siam Nagari Pandam Gadang Kecamatan Gunuang Omeh Kabupaten Lima Puluh

\begin{tabular}{|c|c|c|c|}
\hline $\begin{array}{l}\mathrm{N} \\
\mathrm{O}\end{array}$ & $\begin{array}{l}\text { Jumlah } \\
\text { Batang }\end{array}$ & Frekuensi & $\begin{array}{c}\text { Persentas } \\
\mathrm{e}\end{array}$ \\
\hline 1 & $\begin{array}{c}50 \\
\text { batang }\end{array}$ & 10 & 50,0 \\
\hline 2 & $\begin{array}{c}70 \\
\text { batang }\end{array}$ & 7 & 35,0 \\
\hline 3 & $\begin{array}{c}100 \\
\text { batang }\end{array}$ & 3 & 15,0 \\
\hline \multicolumn{2}{|c|}{ Jumlah } & 20 & $100 \%$ \\
\hline
\end{tabular}
Kota Di Nilai Dari Segi Produksi, Harga Jual, Pendapatan

\section{Produksi}

Tabel 1. Jumlah Batang Jeruk

Sumber: Pengolahan Data Primer

Dari tabel 1 di atas menjelaskan bahwa jumlah batang jeruk yang dimiliki oleh responden berbeda-beda, semakin luas perkebunan jeruk tentu jumlah batang yang dimiliki oleh responden semakin banyak

Total hasil panen jeruk responden di Kecamatan Gunuang Omeh bermacam-macam, hal ini tentu dipengaruhi oleh jumlah batang jeruk yang dimiliki oleh responden, semakin banyak batang jeruk tentu hasil panennya juga meningkat.

\section{Harga Jual}

Tabel 2. Perbandingan Jumlah Petani dalam memasarkan buah Jeruk

\begin{tabular}{|c|l|c|c|}
\hline No & $\begin{array}{l}\text { Alternatife } \\
\text { Jawaban }\end{array}$ & Frekuensi & Persentase \\
\hline 1 & $\begin{array}{l}\text { Melalui } \\
\text { Toke }\end{array}$ & 11 & 55,00 \\
\hline 2 & $\begin{array}{l}\text { Langsung } \\
\text { jual ke pasar }\end{array}$ & 9 & 45,00 \\
\hline \multicolumn{2}{|c|}{ Jumlah } & 20 & $100 \%$ \\
\hline
\end{tabular}

Sumber: Pengolahan Data Primer

Dari tabel 2 di atas menjelaskan bahwa temuan dilapangan, responden hanya memasarkan jeruk melalui agen dan langsung dujual oleh responden dipasar terdekat. Berikut ini adalah tabel hasil responden yang menjual jeruk melalui toke dan langsung menjual kepasar.

\section{Pendapatan}

Tabel 3. Pendapatan yang diterima oleh toke

\begin{tabular}{|c|c|c|c|}
\hline No & $\begin{array}{c}\text { Pendapatan } \\
\text { melalui agen }\end{array}$ & frekuensi & Persentase \\
\hline 1 & Rp 1.000.000 & 6 & 30,00 \\
\hline 2 & Rp 2.000.000 & 14 & 70,00 \\
\hline \multicolumn{2}{|c|}{ Jumlah } & 20 & $100 \%$ \\
\hline
\end{tabular}

Sumber: Pengolahan Data Primer

Dari tabel 3 di atas menjelaskan bahwa pendapatan yang didapatkan oleh responden tentu dipengaruhi oleh jumlah produksi jeruk yang didapatkan oleh responden semakin banyak jumlah produksi jeruk tentu pendapatan yang didapatkan semakin tinggi. 
Berikut ini adalah perbandingan pendapatan yang didapatkan dari penjualan buah jeruk antara menjual ketoko dengan menjual langsung kepasar

\section{Faktor-Faktor}

Yang

Mempengaruhi Potensi Ekonomi Perkebunan Jeruk Siam Pandam Gadang Kecamatan Gunuang Omeh Kabupaten Lima Puluh Kota.

Luas lahan yang dimiliki oleh petani berkisar di antara $250 \mathrm{~m}^{2}$ sampai dengan $500 \mathrm{~m}^{2}$ atau kira kira setengah hektar yang bisa menampung sekitar 100 batang jeruk, selain itu petani yang memiliki halaman yang luas di perkarangan rumah, bisa memanfaatkannya untuk menanam sekitar beberapa buah batang jeruk, dikarenakan lahan perkebunan yang tidak mencukupi. Selain itu akses jalan menuju perkebunan juga terjanggal oleh jalan-jalan berbukitan yang digunakan petani jeruk untuk menanam jeruk, namun ada juga sebagian petani yang memiliki perkebunan jeruk di pinggir-pingir jalan raya.

Modal usaha yang didapatkan oleh petani ada yang berasal dari dana pribadi dan bantuan pemerintah, bantuan dana yang diberikan pemerintah diutamakan untuk kelompok tani jeruk siam Gunuang Omeh, tapi terdapat juga bantuan yang diberikan pemerintah kepada para petani yang memiliki lahan pribadi berupa bantuan pupuk dan pestisida, sedangkan para kelompok tani didanai dari awal mulai dari lahan, pemberian bibit jeruk, hingga pupuk dan perawatan sampai masa panen, pemberian batang bibit jeruk pun bervariasai ada 70-100 batang, pemberian pupuk dan pestisida lebih kurang 2 karung.

Pelatihan dan penyuluhan yang diberikan pemerintah kepada para petani jeruk siam Gunuang Omeh belum merata, dari hasil wawancara penulis kepada beberapa petani hanya petani jeruk yang memiliki kelompok tani yang diberikan penyuluhan, bahkan kelompok tani digabungkan menjadi satu meskipun hasil pertanian nya berbeda-beda, misalkan kelompok tani jeruk dan kacang tanah, itu tergabung dalam satu kelompok tani sedangkan para petani jeruk yang memiliki lahan pribadi sampai saat ini belum merasakan penyuluhan dan pelatihan yang diberikan kepada kelompok tani, sehingga para petani yang memiliki lahan pribadi masih kesulitan dalam mengembangkan dan meningkatkan jumlah panen jeruk siam nya, karena para petani juga membutuhkan pengetahuan dan bantuan dana bagaimana cara mengembangkan hasil panan jeruk siam.

\section{PEMBAHASAN}

1.Potensi Ekonomi Perkebunan Jeruk Siam Nagari Pandam Gadang Kecamatan Gunuang Omeh Kabupaten Lima Puluh Kota Di Nilai Dari Segi Produksi, Harga Jual, Pendapatan.

Jumlah batang jeruk yang ditanam akan mempengaruhi hasil 
produksi jeruk yang ditanam dimana $50 \%$ petani jeruk siam di Nagari batang jeruk sebanyak 50 batang dengan hasil panen yang
Pandam Gadang memiki jumlah dihasilkan rata-rata memilki berat $100 \mathrm{~kg}$ untuk setiap kali panen jeruk.

Tabel 4. Luas panen, produktivitas, dan produksi jeruk di Kabupaten Lima Puluh Kota 2016

\begin{tabular}{|c|c|c|c|}
\hline No & Kecamatan & Produksi (ton) & Produktivitas(ton/ha) \\
\hline 1 & Situjuah Limo Nagari & 17.90 & 17.01 \\
\hline 2 & Guguak & 37.60 & 19.66 \\
\hline 3 & Mungka & 8.30 & 22.90 \\
\hline 4 & Bukik Barisan & 48.70 & 24.29 \\
\hline 5 & Gunuang Omeh & 7.848 .10 & 23.73 \\
\hline 6 & Kapur IX & 5.50 & 18.33 \\
\hline 7 & Pangkalan Koto Baru & 28.30 & 26.02 \\
\hline
\end{tabular}

Sumber : Badan Pusat Statistik 2016

Berdasarkan tabel 4 dapat

diketahui bahwa Kecamatan

Gunuang Omeh merupakan daerah dengan kontribusi jeruk siam paling besar jika dibandingkan dengan Kecamatan lainnya yang berada di Kabupaten Lima Puluh Kota. Berdasarkan tabel diatas bahwa produksi jeruk siam di Kecamatan Gunuang Omeh paling tinggi sebesar 7.848.1 ton pada tahun 2016, dengan kontribusi sebesar $95.37 \%$ untuk produksi jeruk di Kabupaten Lima Puluh Kota

Dari hasil penelitian penulis diatas dapat kita lihat bahwa harga jual jeruk siam di Nagari Pandam Gadang memiliki harga yang beragam-ragam dan bervariasi, hal ini dikarenakan untuk memasarkan jeruk siam ini untuk sampai kepada konsumen dilakukan melalui 2 cara yaitu melakukan transaksi penjualan melalui agen yang menjemput dan membeli secara langsung jeruk siam kepada petani jeruk dan yang kedua dengan cara petani langsung menawarkan jeruknya kepada penjual maupun pembeli yang berada di pasar.

Harga jual jeruk yang dijual petani langsung kepada agen berada dikisaran harga RP 10.000 per $\mathrm{kg}$ dengan presentase sebesar $75 \%$ sedangkan untuk harga jeruk Rp 8000 per $\mathrm{kg}$ memiliki presentase sebesar $25 \%$. Hal ini membuktikan bahwa nilai jual jeruk yang dibeli oleh agen kepada petani berada dikisaran harga Rp 10.000 per kg. untu harga jeruk yang dijual oleh petani jeruk langsung ke pasar para petani dapat menjual jeruk dengan harga Rp 20.000 per kg nya, dengan presentase sebesar $80 \%$ sedangkan untuk harga jeruk dengan harga $\mathrm{Rp}$ 18.000 per $\mathrm{kg}$ nya memiliki presentase sebesar $20 \%$. Dengan demikian harga jeruk yang dijual petani langsung ke pasar memiliki nilai ekonomis yang jauh lebih tinggi dari pada menjual hasil panen jeruk 
kepada para agen, bahkan jika kita lihat harga jual jeruk yang dipasaran

Pendapatan petani jeruk siam Gunuang Omeh Nagari Pandam Gadang tentu akan dipengaruhi oleh jumlah produksi serta nilai jual jeruk yang dilakukan oleh petani jeruk. Baik itu penjualan yang dilakukan kepada agen maupun penjualan yang dilakukan langsung ke pasar, tentu hasil pendapatan yang didapatkan petani pun akan berbeda-berbeda tergantung dari banyaknya jeruk yang dijual serta kesepakatan harga petani dengan penjual. Untuk petani jeruk siam Nagari Pandam Gadang yang rata-rata memiliki sekitar 50 batang jeruk dengan jumah produksiya untuk setiap kali panen sekitar $100 \mathrm{~kg}$ jeruk akan memiliki pendapatan yang berbeda-beda, karena proses penjualan jeruk dilakukan melalui agen dan penjualan langsung ke pasar.

\section{Faktor-Faktor}

Yang

Mempengaruhi Potensi Ekonomi Perkebunan Jeruk Siam Pandam Gadang Kecamatan Guanuang Omeh Kabupaten Lima Puluh Kota

Setiap tahun Pemkab Lima puluh kota, melalaui dinas tanaman pangan, Hortikultura dan Perkebunan lima Puluh Kota, selalu berupaya mengembangkan dengan memperluas lahan tanaman jeruk siam Gunuang Omeh, dengan harapan produksi jeruk siam Gunuang Omeh akan terus meningkat. Pada tahun 2015 luas bisa mencapai 2 kali lipat dari pada menjual jeruk langsung kepada agen.

tanaman kebun jeruk siam Gunuang Omeh bertambah 106 ha yang dikelola oleh puluhan kelompok tani. Sehingga kebun jeruk siam yang mendapat bantuan pemerintah sudah lebih dari 350 hektare. Belum termasuk puluhan kebun jeruk yang dikelola petani secara perorangan.

Keadaan luas lahan yang ada di perkebunan jeruk siam di Nagari Pandam Gadang Kecamatan Gunuang Omeh saat ini masih dinilai kurang luas oleh para petani jeruk yang berada di sekitar Pandam Gadang. Rata-rata petani jeruk yang memiliki lahan pribadi hanya memiliki luas sekitar $250 \mathrm{~m}^{2}$ sampai $500 \mathrm{~m}^{2}$ yang hanya bisa menanam kira-kira 50 buah batang bibit jeruk siap panen. Sedangkan luas lahan untuk kelompok tani bisa sekitar 500 $\mathrm{m}^{2}$ sampai 1 hektar luasnya yang bisa menanam hingga 200 batang bibit jeruk.

Petani yang memiliki kelompok tani jeruk mendapatkan sumber dana yang mutlak diberikan oleh pemerintah baik itu berupa lahan petanian, bibit batang jeruk serta pupuk dan hama. Pemberian bibit batang jeruk kepada kelompok tani berkisar anta 70-100 batang untuk luas lahan $500 \mathrm{~m}^{2}$. Sedangkan untuk para petani jeruk yang memiliki lahan pribadi ada yang sebagian petani yang mendapatkan 
modal usaha dari pemerintah berupa uang untuk pembelian pupuk.

Modal usaha yang diberikan oleh pemerintah dapat dikembalikan setiap tahunnya berdasarkan hasil panen dan jumlah panen yang dihasilkan. Jika petani jeruk telah mampu untuk mandiri dalam budidaya jeruk siam Gunuang Omeh, maka pemerintah menjanjikan akan memperluas lahan dan menambah modal usaha untuk meningkatkan panen jeruk siam Gunuang Omeh. Namun persoalan modal usaha tidak hanya berkaitan dengan uang saja, kemampuan petani dalam mencari modal melalui koperasi juga perlu ditingkatkan, saat ini koperasi yang ada di Nagari Pandam Gadang belum mampu mengelola peminjaman dana kepada petani dengan baik, padahal pengaruh koperasi sangatlah besar untuk menambah dana bagi para petani sebagailangkah awal untuk meningkatkan hasi panen.

Pendidikan formal petani yang masih rendah menyebabkan pengetahuan dan pengembangan sektor pertanian tidak berkembang dan cenderung monoton menggantungkan hidupnya pada sektor pertanian tanpa menciptakan inovasi-inovasi terbaru demi meningkatkan hasil pangan yang berlimpah. Hasil panen yang tidak seberapa menyebabkan petani tidak memiliki modal untuk mengembangkan usahanya yang menjadi salah satu faktor petani kurang sejahtera di Indonesia. Serta menyebabkan tingginya tingkat kemiskinan di Indonesia.

Keterbatasan pengetahuan yang dimiliki oleh petani Jeruk Siam Gunuang Omeh menyebabkan petani jeruk siam hanya sekedar bertani saja, tanpa memikirkan peluang yang ada untuk mengembangkan usaha taninya.Pemerintah daerah yang datang pun kepada petani sebagai penyuluh hanya memberikan penyuluhan kepada petani yang memiliki kelompok tani, sedangkan petani yang memiliki lahan sendiri tidak mendapatkan penyuluhan dari pemerintah.

Penyuluhan yang diberikan oleh pemerintah daerah terhadap petani jeruk siam Gunuang Omeh pun belum memberikan dampak yang apa-apa terhadap perkembangan kelompok tani jeruk siam Gunuang Omeh. Para penyuluh seharusnya membuka ide atau memberikan gambaran bagaimana para petani berfikir untuk mengembangkan hasil panennya menjadi nilai ekonomis yang lebih tinggi seperti membuka lahan agrobisnis wisata jeruk. Karena penyuluhan yang ada saat ini belum mampu merambah seluruh para petani jeruk yang ada di wilayah Pandam Gadang.

\section{PENUTUP}

\section{A. Kesimpulan}

Potensi ekonomi petani jeruk siam Pandam Gadang Kecamatan Gunuang Omeh dapat dilihat dari 
produksi jeruk, harga jual, serta pendapatan petani setiap kali panen jeruk .Hasil produksi jeruk siam saat ini tergantung kepada jumlah batang jeruk yang ditanam, rata-rata petani jeruk saat ini memiliki 50 batang jeruk siam dengan presentase $50 \%$ dengan hasil produksi jeruk lebih kurang $100 \mathrm{~kg}$ untuk setiap kali panen. Sedangkan untuk harga jual jeruk berkisar diantara Rp 8.000 hingga Rp 10.000 per kg untuk harga yang dibeli langsung oleh agen, dan untuk harga jeruk yang dijual ke pasar oleh petani harga jeruk bisa mencapai 2 kali lipat yaitu berada di kisaran harga Rp 18.000 hingga Rp 20.000 per $\mathrm{kg}$, proses penjualan jeruk ke agen dan langsung ke pasar ini memiliki kelebihan dan kekurangan masing-masing. Pendapatan yang didapatkan oleh petani jeruk siam Nagari Pandam Gadang pun bervariasi karena proses penjualan yang dilakukan dengan 2 proses yaitu dengan agen dan langsung ke pasar.

Pendapatan petani jeruk yang menjual ke agen pendapatan yang diterima adalah Rp 2.000.000 dengan presentase sebesar $70 \%$ sedangkan rata-rata pendapatan yang didapatkan petani jeruk yang menjual ke pasar mendapatkan pendapatan sebesar Rp 3.000.000 dengan presentase sebesar $50 \%$. Dengan demikian pendapatan petani jeruk siam Nagari Pandam Gadang lebih besar jika menjual jeruk ke pasar dari pada menjual jeruk kepada para agen.
Luas lahan yang ada di perkebunan jeruk siam Pandam Gadang saat ini masih sangat terbatas, rata-rata para petani hanya memiliki lahan seperempat hektar yang hanya mampu menampung 50 batang jeruk siam untuk sekali panen. Bahkan sebagian petani ada yang menggunakan lahan di perkarangan rumah. Sangat berbeda dengan kelompok tani yang diberikan lahan yang sangat luas oleh permerintah untuk menanam jeruk hingga 200 batang bibit jeruk setiap kelompok tani

Modal usaha yang digunakan oleh petani jeruk siam Pandam Gadang terdiri dari modal usaha pribadi dan modal usaha pemerintah melalui kelompok tani yang ada, modal usaha yang diberikan kepada kelompok tani berupa bibit jeruk siam, pupuk dan hama pestisida. Jika ada peningkatan dari hasil panen jeruk kelompok tani, maka akan ada penambahan modal untuk kelompok tani

Keterbatasan sumber daya manusia disini adalah minimnya pengetahuan petani untuk meningkatkan hasil panen perkebunan jeruk yang ada, metode yang digunakan oleh para petani masih secara tradisional, penyuluhan yang diberikan saat ini hanya terbatas untuk para petani yang memiliki kelompok tani saja, sedangkan kepemilikaan pribadi belum mendapatkan penyuluhan sama sekali. Salah satu cara yang 
dapat digunakan adalah penggunaan teknologi modern terhadap perkebunan jeruk siam Kecamatan Gunuang Omeh.

\section{DAFTAR PUSTAKA}

BPS Kabupaten Lima Puluh Kota, Gunuang Omeh Dalam Angka 2017

Daniel Mohar. 2004. Pengantar Ekonomi pertanian. Jakarta: PT Bumi Aksara.

Dornbusch, dan Fischer. 2011. Makro ekonomi Penerbit Erlangga.Jakarta
Soekartawi, 1986. Ilmu Usahatani

Dan Penelitian Untuk Pengembangan Petani Kecil. Penerbit Universitas Indonesia, Jakarta.

Sugiyono. (2011). Metode Penelitian Kuantitatif dan Kualitatif. Bandung:CV Alfabeta.

Sudjana (2007) Metode statistika. Bandung.TARSITO 